\title{
Diel and seasonal movements of grumatã Prochilodus lineatus (Valenciennes 1836) (Characiformes: Prochilodontidae) in the Sinos River, Southern Brazil
}

\author{
Pesoa, NA.* and Schulz, UH.* \\ Programa de Pós-Graduação em Ecologia, Laboratório de Ecologia de Peixes - Centro 2, \\ Universidade do Vale do Rio dos Sinos - Unisinos, Av. Unisinos, 950, CEP 93022-000, São Leopoldo, RS, Brazil \\ *e-mail: nicolleap@gmail.com; uwe@unisinos.br \\ Received February 21, 2010 - Accepted April 29, 2010 - Distributed December 31, 2010
}

(With 6 figures)

\begin{abstract}
Prochilodus lineatus is a reophilic migratory species of economical importance for local fisheries which is widely distributed in Brazil. The present study investigated diel and seasonal movement patterns, spawning migration and habitat use of P. lineatus in the Sinos River, Southern Brazil. Between August 2002 and March 2004, 19 grumatãs were tagged internally with digitally coded radio transmitters. Tracking was conducted weekly by boat or aircraft, and six fixed data loggers recorded movements of tagged fish. Results showed that the mean distance covered per fish and day was positively related with fish weight $(\mathrm{p}=0.03 ; \mathrm{n}=19)$. Grumatã showed preference for river streches surrounded by wetlands $(\mathrm{p}<0.001 ; \mathrm{n}=286)$. Their diel activity pattern displayed one peak at 7 hours, and a second at 15 hours. During the night, activity was significantly reduced $(\mathrm{p}=0.01)$. The seasonal movements pattern showed increased activity in October 2002 - March 2003 and from October 2003 to January 2004. Multiple regression analysis did not show a significant relationship between distance covered and temperature or water level $(p=0.116 ; n=19)$. No synchronized long distance spawning migrations were observed. The mean distance covered by the individuals/ day showed a negative significant relationship with number of tracking days $(\mathrm{p}=0.022 ; \mathrm{n}=19)$, indicating a higher probability of being captured for more mobile individuals. The preservation of the still existing wetlands and reduction of the fishing pressure are essential for the future conservation of the grumatã population of the Sinos River.
\end{abstract}

Keywords: radio tracking, movement patterns, activity, spawning migration, habitat use.

\section{Migração e Movimentos do grumatã Prochilodus lineatus (Valenciennes, 1836) (Characiformes, Prochilodontidae) no Rio dos Sinos, sul do Brasil}

\begin{abstract}
Resumo
Prochilodus lineatus é uma espécie migratória, de hábito reofílico e com grande importância como recurso pesqueiro. É uma espécie amplamente distribuída no Brasil. O presente estudo investigou os padrões diários e sazonais de atividades, migrações reprodutivas e uso de hábitat do P. lineatus no Rio dos Sinos, região sul do Brasil. Entre agosto de 2002 e março de 2004, 19 grumatãs foram internamente marcados com rádio transmissores codificados. O rastreamento foi semanalmente conduzido utilizando barco ou avião. Adicionalmente, seis radiorreceptores fixos registraram os movimentos dos peixes marcados. Os resultados mostram que a distância média percorrida por peixe foi positivamente relacionada com peso dos indivíduos $(\mathrm{p}=0.03 ; \mathrm{n}=19)$. Grumatãs mostram preferências significativas por trechos do rio com presença de banhados $(\mathrm{p}<0.001 ; \mathrm{n}=286)$. O padrão nictimeral de atividade mostrou dois picos de atividade, um as 7 horas da manhã, e outro à tarde às 15 horas. Durante a noite, a atividade foi significativamente reduzida $(\mathrm{p}=0,01)$. O padrão sazonal de atividade mostra um aumento de atividade em outubro de 2002 - março de 2003, e de outubro de 2003 a janeiro de 2004. A Análise de Regressão Múltipla não mostrou relação significativa entre a atividade e temperatura ou nível da água $(\mathrm{p}=0,116 ; \mathrm{n}=19)$. Não foram observadas migrações reprodutivas sincronizadas de longa distância. A média da distância percorrida por indivíduo por dia mostrou uma relação significativa negativa com o número de dias monitorados $(\mathrm{p}=0,022 ; \mathrm{n}=19)$, indicando, que indivíduos mais ativos têm uma probabilidade maior de serem capturados. A preservação de áreas úmidas existentes e a redução do recurso pesqueiro pela pressão da pesca são essenciais para a conservação futura da população de grumatãs no Rio dos Sinos.
\end{abstract}

Palavras-chave: radiotelemetria, padrão de movimentos, migração reprodutiva, uso de hábitat. 


\section{Introduction}

Prochilodus lineatus (Valenciennes, 1836), is a widely distributed species in South America. Its name in Portuguese is grumatã or curimbatã, and sabalo in Spanish. In the Paraná, Paraguay and Uruguay rivers basins, the species is very abundant. In the lower Paraná River, about $10.000 \mathrm{t}$ of freshwater fish are landed per year, of which $P$. lineatus makes up to $95 \%$ (Espinach-Ros and Delfino, 1993). Prochilodus scrofa (Steindachner, 1881) and Prochilodus platensis (Holmberg, 1891) are considered synonyms of P. lineatus (Froese and Pauly, 2010).

The grumatã is a detrivorous species, feeding on fine bottom sediment containing organic particles (Fugi et al., 1996) and on periphyton, which contributes considerably for nutrient intake of the species (Bowen et al., 1984). Maximum reported total length is $78 \mathrm{~cm}$ (Castro and Vari, 2003) but most individuals range in size from 30 to $40 \mathrm{~cm}$. Adult $P$. lineatus prefer lotic environments whereas juveniles are most frequently found in marginal lagoons of the main river channel. In these habitats they can make up to $80 \%$ of the biomass (Gomes and Agostinho, 1997).

Reproduction occurs in the main river channel at the water surface. Usually grumatã spawns in large schools during the Southern hemisphere summer (November to January). The eggs are semi dense and are dispersed downriver by the current (Zaniboni and Schulz, 2003). The larvae hatch at approximately 600 degree hours, and three days after hatching, larvae begin feeding on plankton. Marginal lagoons or backwaters are essential for larval development. In rivers without these lateral structures, like the headwaters of the Uruguay River, the mouths of tributaries are likely to be the nursery areas (Zaniboni and Schulz, 2003). Adult individuals live predominantly in the main river stem, usually in areas of low water flow, like oxbows and other lateral structures (Sverlij et al., 1993). Juveniles grow fast; males may attain $20 \mathrm{~cm}$ in the first year and may already be mature after the first year of life (Agostinho et al., 1993). Maximum age was reported to be nine years, with individuals between three and six years most abundant in lower River Uruguay populations (Sverlij et al., 1992).

Early experiments with conventional LEA tags in the upper Paraná River by Godoy (1962) revealed that grumatãs are capable of migrating more than $1000 \mathrm{~km} . \mathrm{y}^{-1}$. However, distances between 450 and $600 \mathrm{~km}$ are more common (Bayley, 1973; Agostinho et al., 1993; Espinach-Ros and Delfino, 1993). During spawning migration fish swim upstream between 10 and $16 \mathrm{~km} \cdot \mathrm{d}^{-1}$, exceptionally covering up to $43.7 \mathrm{~km} \cdot \mathrm{d}^{-1}$. Migrating fish store large amounts of fat in the body cavity (Godoy, 1962). Many authors agree that the onset of spawning migration is triggered by an increase in water level and temperature (Schubart, 1954; Godoy, 1962; Bayley, 1973; Agostinho et al., 2003). Several studies indicate that grumatã home to spawning sites. Godoy (1959) found tagged P. lineatus in the same spawning areas in consecutive years. Prochilodus argenteus (Spix and Agassiz, 1829), a closely related species in the
São Francisco River homed to pre-spawing (staging) and spawning sites (Godinho and Kynard, 2006).

Like many other migrant species, grumatã populations have been suffering serious declines in several watersheds. The most important reasons for this development are the obstructions of migration routes by hydroelectric power plants, alterations of the natural flow regime governed by the economic demands of the power plants, habitat destruction (particularly by transformation of wetlands in rice paddies or pasture), pollution, and heavy fishing pressure. A review of the status of the South American migratory fishes is given by Carolsfeld et al. (2003).

In the Sinos River Basin, numbers of grumatãs have decreased during the last 20 years, according to anecdotal reports by fishermen. They report that large spawning schools could be heard from a distance when huge numbers of males produced a characteristic "snoring" sound during reproduction in the spring-summer transition from November to December, with increasing temperature and water levels. Godinho and Kinard (2006) mentioned sound production in $P$. argenteus when the species reached the spawning sites in the São Francisco River.

It is a common saying in the region that fish were so numerous that fishermen could capture a cart-load in a few hours. The present population decline has probably been caused by regional impacts such as pollution of the middle and lower stretches, habitat degradation of the upper and middle reaches, and illegal fishing. The physical structure of the main River channel, however, has not been severely altered. Although the former large spawning schools have disappeared, grumatã is still an abundant species in the Sinos basin.

The objectives of the study focus on the following issues:

i) the investigation of spawning migrations;

ii) the identification of spawning areas;

iii) the identification of the principal areas of sojourn;

iv) the identification of diel movement patterns; and

v) on the evaluation of the effects of the fishing pressure.

\section{Material and methods}

\subsection{Study area}

The Sinos River Basin covers an area of $4002 \mathrm{~km}^{2}$ and is located between latitudes $29^{\circ}$ and $30^{\circ}$ in Brazil's Southern most State of Rio Grande do Sul. Mean discharge is about $70 \mathrm{~m}^{3} \cdot \mathrm{s}^{-1}$ and the total extension is $190 \mathrm{~km}$ (FEPAM, 1999). The Sinos River originates in the mountainous region of Serra Geral at an altitude of $700 \mathrm{~m}$ in the municipality of Caraá and falls into the Lake Guaíba, near the State capital, Porto Alegre. The uppermost stretch of $25 \mathrm{~km}$ is characterised by a high gradient, including sequences of riffles and pools and stable banks (B-type; according to Rosgen, 1994). From Monjolo (River km 140 from the mouth of the River) the Sinos River enters the lowland section, displaying the characteristics of an E-type River 
with high meander-width ratio, low width-depth ratio, low gradient and low deposition (Rosgen, 1994).

Lateral connectivity of the riverbed increases, and several tributaries enter the main river stem (Figure 1). Seasonally flooded wetlands are still present, particularly in the lower reach.

Water quality gradually decreases from class two in the headwaters to class four in the lowland reaches, which is the worst score of the official Brazilian ranking system (CONAMA, 1992). Historically, the basin was the centre of development of the Brazilian leather industries. Tanneries produced sewage with high loads of heavy metal, especially chrome. At present, a shift to metallurgic industries has been occurring. Due to stricter environmental laws, the concentration of heavy metals has declined over the past 20 years. At present, domestic sewage is considered to be the major problem affecting water quality of the Sinos River. In the entire watershed, only one municipality out of 22 operates sewage treatment plants.

Fishery in the Sinos River is weakly controlled. Most fishermen are not licensed, fishing continues during the closed season from November to January and mesh size regulations are not obeyed.

\subsection{Fish tagging}

Test fish were captured by gillnets of licensed fishermen associated with the project between August 2002 and October 2003 in the stretch of river between São Leopoldo and Novo Hamburgo (Table 1). Nineteen grumatã in good physical condition were selected for tagging. After capture, the fish were measured (total length) and weighed. Minimum weight for selection was $500 \mathrm{~g}$. All selected individuals were potentially mature fish. Minimum weight for reproduction in regional fish farms is about $400 \mathrm{~g}$.

The fish were anesthetised (2-phenoxyethanol $350 \mathrm{mg} . \mathrm{L}^{-1}$ ) and the transmitter was implanted surgically into the peritoneal cavity through a $4 \mathrm{~cm}$ ventral incision according to the procedure described in Adams et al. (1998). The antenna protruded from the body wall about $1.5 \mathrm{~cm}$ posterior to the incision. The antenna was conducted through the body wall by the shielded-needle method with a veterinarian syringe $(100 \times 2 \mathrm{~mm})$ serving as a catheter. The incisions were closed with three or four stitches of non-absorbable monofilament suture (Ethicon Ethipoint SC-20). To keep the fish anesthetized and to avoid drying of the gills, $0.2 \mathrm{~mL} . \mathrm{L}^{-1}$ phenoxy-ethanol solution was applied to the gills during the surgery. The transmitters were digitally coded Lotek MCFT-3FM models with $149 \mathrm{MHz}$ frequency, $10 \mathrm{~g}$ weight, burst rate of $5 \mathrm{~s}$ and 336 days expected battery life. Tagged fish were released after surgery at the capture site.

\subsection{Data collection and treatment}

Data on fish movements were collected from August 2002 to March 2004. Tracking was performed by six automatic listening stations (ALS; Lotek SRX-400 W8 data logger equipped with one 4-element yagi antenna) deployed along the river and by mobile tracking (Lotek SRX-400 W5 with 2-element yagi antenna). ALS were deployed at river $\mathrm{km}$ $2(\mathrm{~km} 0=$ river mouth) in the city of Canoas, at $\mathrm{km} 44$ (São Leopoldo), at km 54 (Novo Hamburgo), at km 73 (Sapiranga), at km 100 (Taquara) and the uppermost in Pinheirinhos at km 133 (Figure 1). The distance between the units varied between 10 and $42 \mathrm{~km}$.

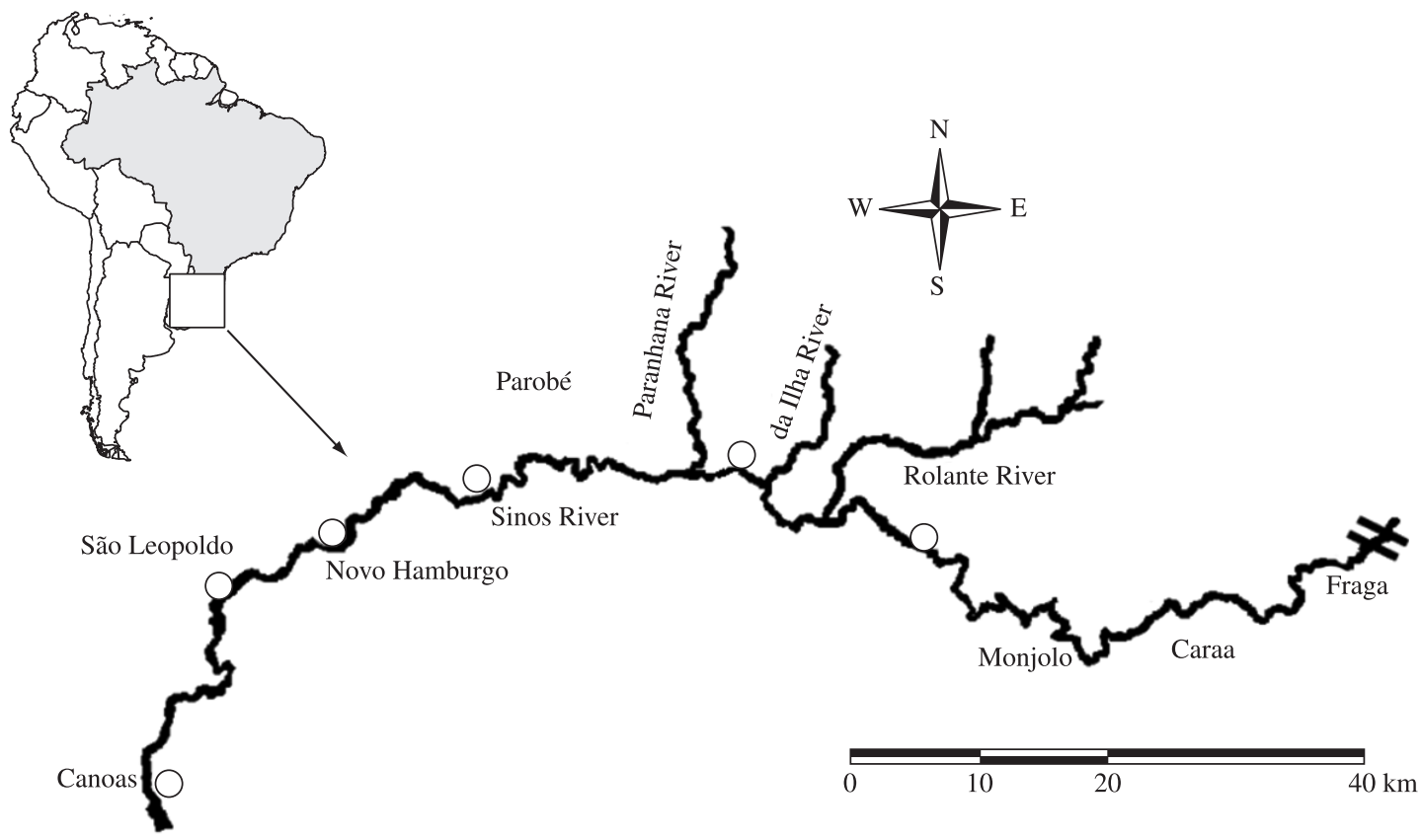

Figure 1. Study area with deployment sites of Automatic Listening Stations (०). 
Table 1. History of the tagged individuals.

\begin{tabular}{cccccccccc}
\hline $\begin{array}{c}\text { Transmitter } \\
\text { number }\end{array}$ & $\begin{array}{c}\text { Tagging } \\
\text { date }\end{array}$ & $\begin{array}{c}\text { Weight } \\
\text { (g) }\end{array}$ & $\begin{array}{c}\text { Total } \\
\text { length } \\
\text { (cm) }\end{array}$ & $\begin{array}{c}\text { Expected } \\
\text { transmitter } \\
\text { life until }\end{array}$ & $\begin{array}{c}\text { Last } \\
\text { position } \\
\text { fix }\end{array}$ & $\begin{array}{c}\text { Number } \\
\text { of position } \\
\text { fixes }\end{array}$ & $\begin{array}{c}\text { Total distance } \\
\text { covered } \\
\text { (km) }\end{array}$ & $\begin{array}{c}\text { Tracking } \\
\text { period } \\
\text { (d) }\end{array}$ & $\begin{array}{c}\text { Mean } \\
\text { distance/day } \\
\text { (m) }\end{array}$ \\
\hline 25 & 22/Aug./02 & 712 & 27.2 & July/03 & 03/Sept./03 & 36 & 56.5 & 349 & 161.9 \\
34 & 22/Aug./02 & 672 & 39 & July/03 & 26/Sept./03 & 42 & 35.8 & 399 & 89.8 \\
43 & 22/Aug./02 & 883 & 31 & July/03 & 28/Oct./03 & 10 & 45.3 & 66 & 686.6 \\
70 & 22/Aug./02 & 782 & 39 & July/03 & 13/Mar./03 & 7 & 2.8 & 209 & 13.7 \\
17 & 06/Sept./02 & 865 & 38.5 & Aug./03 & 22/Sept./03 & 34 & 62.4 & 378 & 165.1 \\
8 & 11/Mar./03 & 739 & 38 & Feb./04 & 16/Nov./03 & 18 & 62.7 & 245 & 256.2 \\
26 & 9/June/03 & 510 & 34 & May/04 & 22/Oct./03 & 16 & 6.5 & 133 & 49.2 \\
28 & 9/June/03 & 599 & 37 & May/04 & 4 /Mar./04 & 40 & 45.9 & 275 & 167.0 \\
29 & 9/June/03 & 547 & 34.5 & May/04 & 21/Nov./03 & 17 & 29.6 & 162 & 182.8 \\
27 & 16/June/03 & 573 & 33.5 & May /04 & 20/Feb./04 & 24 & 139.0 & 244 & 569.7 \\
44 & 16/June/03 & 568 & 35 & May/04 & 20/Feb./04 & 10 & 16.5 & 244 & 67.5 \\
74 & 23/June/03 & 1009 & 45 & May/04 & 20/Feb./04 & 25 & 85.0 & 236 & 360.5 \\
20 & 30/Oct./03 & 841 & 38.5 & Sept./04 & 27/Jan./04 & 6 & 45.4 & 86 & 527.5 \\
24 & 30/Oct./03 & 831 & 39 & Sept./04 & 4/Mar./04 & 14 & 102.7 & 123 & 835.2 \\
21 & 30/Oct./03 & 790 & 37 & Sept./04 & 4/Mar./04 & 16 & 99.1 & 123 & 805.2 \\
$26 a$ & 30/Oct./03 & 827 & 37.6 & Sept./04 & 4/Mar./04 & 9 & 61.9 & 123 & 503.6 \\
6 & 30/Oct./03 & 961 & 38.5 & Sept./04 & 18/Dec./03 & 5 & 18.9 & 48 & 393.5 \\
5 & 30/Oct./03 & 845 & 39.5 & Sept./04 & 8/Jan./03 & 6 & 34.4 & 68 & 505.8 \\
62 & 30/Oct./03 & 627 & 35.5 & Sept./04 & 01/Oct./04 & 9 & 7.1 & 123 & 58 \\
\hline
\end{tabular}

Stored data were downloaded at two-week intervals. The ALS registered the presence of an individually coded radio signal, its signal power, date and time of occurrence. Beside true signals, the ALS recorded false signals due to electronic noise in the environment. A signal was counted as valid when a transmitter code actually used at the time of occurrence was registered twice within one minute at a signal power higher than $50 \mathrm{dBm}$. The number of registered signals is not necessarily an indicator of activity, because immobile fish which stay within the reach of the reception antenna produce many signals. For ALS data evaluation, activity was defined as number of fish passages at deployment sites. Consecutive signals with a time lag of less than 10 min were counted as one passage, signals with a time lag of more than $10 \mathrm{~min}$ were counted as two passages (back and forth movement).

ALS passages were used to determine grumatã diel activity. To establish the diel pattern, fish passages were summed up for each hour of the day during the entire investigation period. For graphical presentation, the pattern was smoothed by calculating three moving means (Schulz and Berg, 1987).

Mobile tracking was usually performed at weekly intervals. When navigation by boat was not possible, during droughts or dangerous floods, grumatãs were located by aircraft. During mobile tracking, the location with the strongest signal power was considered to be the fish position. Geographical coordinates (UTM) were identified by a handheld GPS (Garmin GPS Plus III). The accuracy of position fixes was about $200 \mathrm{~m}$ for aerial and $20 \mathrm{~m}$ for boat tracking.
Geographical coordinates were included on a digitalised map, based on the 1:50.000 scale maps of the Brazilian Ministry of Defense. All position fixes were transformed into distances from the river mouth. Consequently, the difference between two subsequent measures corresponds to the distance covered during this interval.

Daily temperature readings and water levels fluctuations were provided by COMUSA, the water supplying company of the city of Novo Hamburgo. These environmental variables and the mean distance covered per individual and month were $\log (\mathrm{x}+1)$ transformed to meet normality and homoscedasticity requirements of multiple regression (backward elimination).

\section{Results}

During the study period of 19 months, 19 grumatã were tagged with radio transmitters. Total length of tagged fish varied between 27.2 and $45.0 \mathrm{~cm}$, the weight of the smallest fish was $510 \mathrm{~g}$ and the biggest was $1009 \mathrm{~g}$ (Table 1). Only four individuals could be tracked until the transmitter battery expired, eight were still transmitting signals at the end of the study and seven fish were lost. All tagged individuals moved at least one kilometer during the first four weeks after surgery.

The ALS and mobile tracking produced a total of 361 position fixes. During periods of high water levels, tracking was more difficult, because fish dispersed in the floodplain and could not be located accurately in the dense vegetation of the flooded wetlands.

Grumatã 27 could be tracked during 244 days with 24 positions, fish 24 was tracked for 123 days with 
13 positions, fish 39 was tracked $2.8 \mathrm{~km}$ for 209 days but produced only seven positions (Table 1 ). The most active fish (24) covered $102.7 \mathrm{~km}$ in 123 days $\left(0.83 \mathrm{~km} . \mathrm{d}^{-1}\right)$ (Table 1).

Swimming activity of grumatãs was positively correlated with weight. A linear regression showed that the mean distance covered per day was higher for fish of higher weight $(\mathrm{F}=5.135, \mathrm{p}=0.03)$. Mean total length was not significantly correlated with mean covered distance $(\mathrm{p}=0.715)$.

All fish locations observed during the study were restricted to the river stretch between 2 and $118 \mathrm{~km}$ from the river mouth. Within these $116 \mathrm{~km}$, the tagged individuals displayed a preference for the river reach between kilometers 30 to 60 , which contained $73 \%$ of all fixes. This stretch is characterized by the presence of wetlands. Of all 361 position fixes registered throughout the study, 286 fell in river stretches surrounded by wetlands, indicating a highly significant preference for these habitats (Chi-square test; $\mathrm{p}<0.001$ ). On four occasions, at high water levels during the summer, schooling grumatãs were observed in these areas, apparently spawning. One fish (number 8 ) was registered leaving the monitoring area by passing the most downriver located ALS at Canoas. This individual was not discovered again by aerial or boat tracking, but was registered six months later by the same ALS. Three other fish made excursions to the river mouth and returned.

The diel pattern, based on 84 valid fish passages (false positive signals excluded) at ALS deployment sites, showed that grumatãs were more active during the day (6 AM to $6 \mathrm{PM}$ ) than during the night (Chi-square test; $p=0.01$; Figure 2 ). There were two activity peaks during the day, one in the morning around 7 hours and the other at 15 hours.

During long periods, grumatãs were not mobile and did not display extended movements (Figure 3). During these resident periods, fish moved within a restricted area.
These periods with few movements were interrupted by unpredictable excursions. In most cases grumatã individuals returned to the same river stretch after an excursion. The low mobility was confirmed by the record of only 84 fish passages at six ALS of the 19 tracked individuals during 19 months.

Seasonal migration patterns were not evident. Although excursions of up to $70 \mathrm{~km}$ occurred during the spawning season, a mass spawning migration involving almost all tagged individuals was not observed. Long distance excursions did not occur more frequently during the spawning season either (Figure 4). Few individual fish performed excursions of more than $30 \mathrm{~km}$, but most individuals did not. The mean distance covered per individual and month during spawning season from November to January was $10.4 \mathrm{~km}$ (15.66 S.D.; $\mathrm{n}=60)$. During the rest of the year, the mean value declined almost $50 \%$ (4.2 km; 6.9 S.D.; $\mathrm{n}=56$ ), but this difference was not significant (Student$t$-test; $\mathrm{p}=0.066)$.

As temperature and water level are considered to be triggers for migrations, multiple linear regression with mean covered distance per individual and month as dependent variable and mean temperature and water level per month as predictor variables was applied. No significant relation was detected $(\mathrm{p}=0.79)$. The monthly covered distance displayed higher values in March 2003, when the spawning season had probably terminated (Figure 5). During this month, water temperature was already decreasing, while some flood events caused a peak in water level. Only during the next spawning season mobility of tagged fish increased with temperature and remained elevated during high water levels. During the study mobile individuals were lost earlier than resident fish. Considering the period which each individual could be tracked (= tracking days) and the mean distance covered per day, a significant negative linear relation was found $(\mathrm{F}=6.380 ; \mathrm{p}=0.022$; $\mathrm{n}=19$ ) (Figure 6).

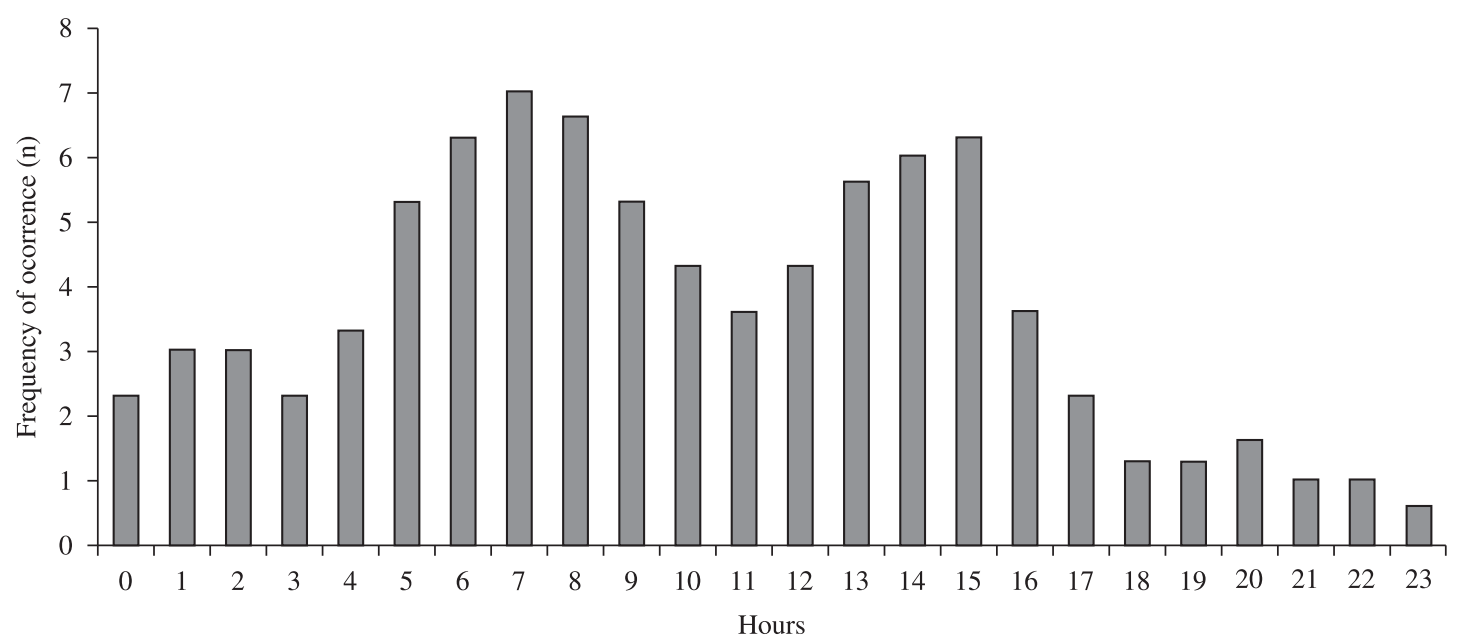

Figure 2. Diel movement pattern adjusted by three moving means $(\mathrm{n}=88)$. 

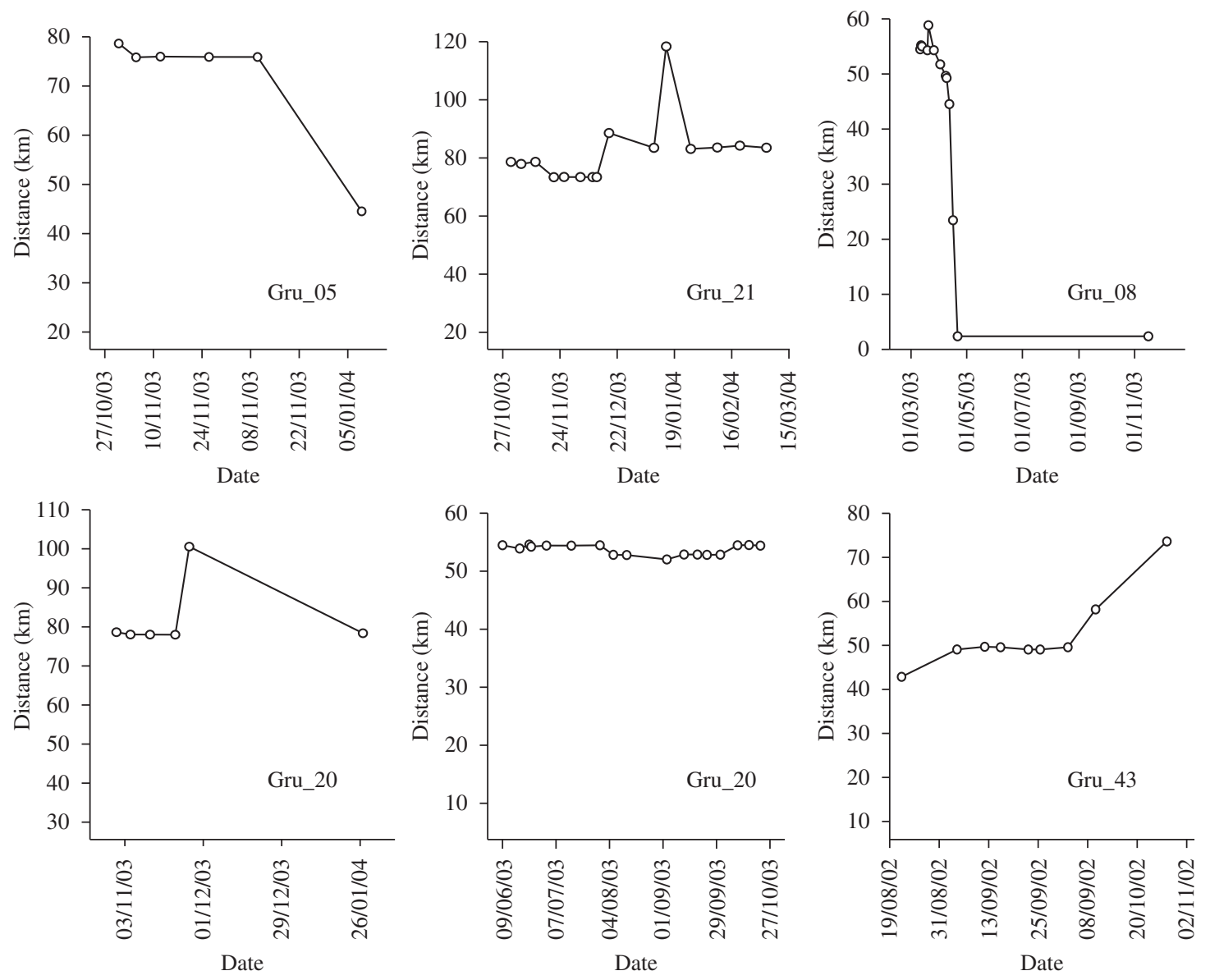

Figure 3. Resident periods and excursions of six grumatã.
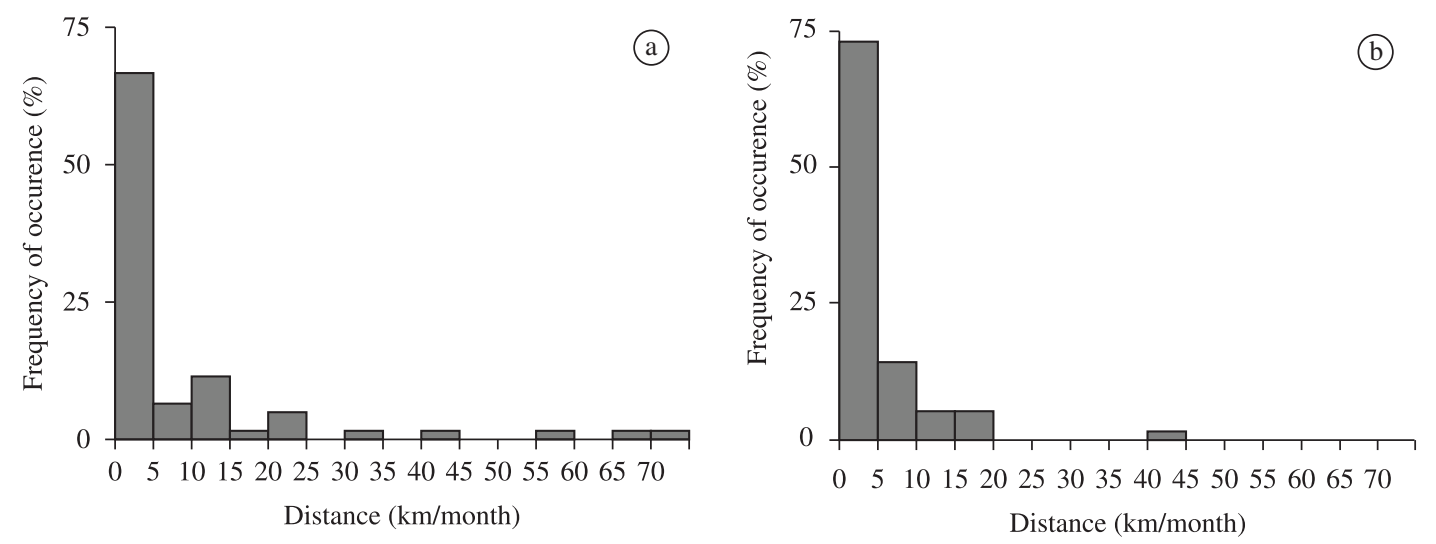

Figure 4. Mean covered distance per month during spawning season a) November to January and b) off spawning season.

\section{Discussion}

No tagging mortality occurred after surgery, since all tagged fish moved at least one kilometer in the month after tagging. In previous tests using the tagging method, incisions closed within two weeks and no negative effects were detected for silver catfish (Rhamdia quelen Quoy and
Gaimard, 1824) growth (Schulz, 2003) and movements (Schulz and Leuchtenberger, 2006).

During the study period, larger $P$. lineatus moved longer distances. This seems to be a common phenomenon, although a significant correlation of body weight and mobility does not occur in all species. 


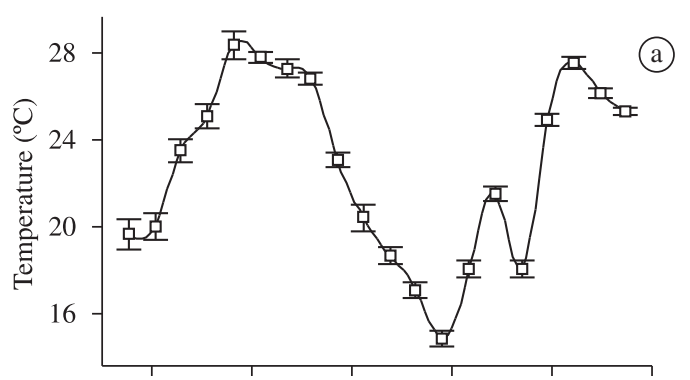

Aug./02 Dec./02 Apr./03 Aug./03 Dec./03 Mar./04 Month

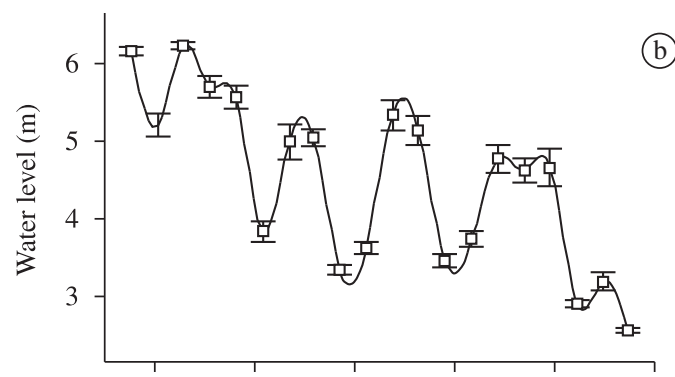

Aug./02 Dec./02 Apr./03 Aug./03 Dec./03 Mar./04 Month

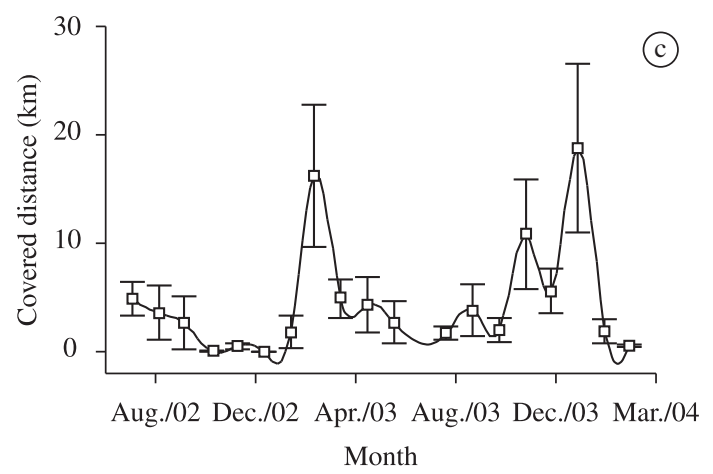

Figure 5. a) Monthly means of temperature, b) water level, and c) movements from August 2002 to March 2004 (bars = standard error).

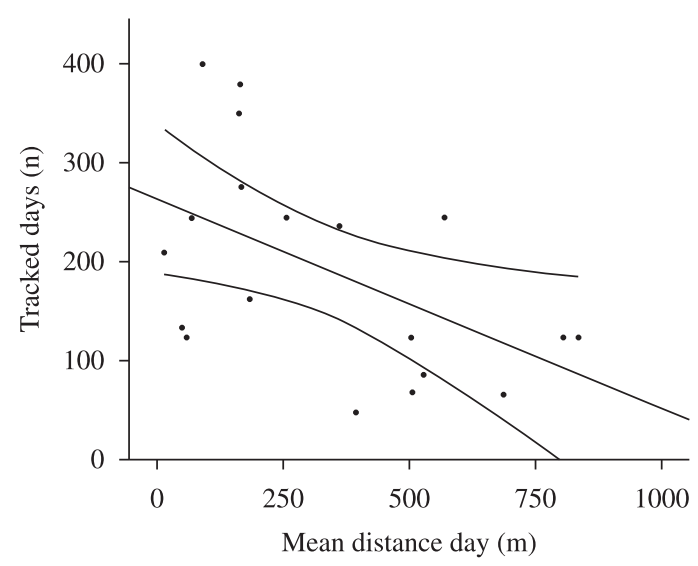

Figure 6. Negative linear regression between number of tracked days per individual and mean covered distance per day $\left(\mathrm{R}^{2}=0.273, \mathrm{n}=19\right)$.
Large South American silver catfish ( $R$. quelen) displayed higher activity levels than small fish (Schulz and Leuchtenberger, 2006). Travinchek (2004) observed the same relation in tagged flathead catfish (Pylodictys olivaris Rafinesque, 1818) in the Missouri River, and Young (1999) in brown trout (Salmo trutta Linnaeus, 1758). Larger fish might have a higher ability to exploit, or, in the case of territorial species, defend larger diel areas (Young, 1999). Mochek and Pavlov (1998) found considerable amounts of fat accumulated in the body cavity of migrating Prochilodus nigricans (Spix and Agassiz, 1829), suggesting that these fish spend this energy resource during migration.

Nine transmitters were lost before the expected end of transmitter life. Of these, three were returned by rewardseeking fishermen. One was located in the residence of an unknown person. Most probably, more tagged fish were captured. Project associated fishermen confirmed that colleagues captured tagged fish, cut the antenna off the transmitter and dumped them into the river. Since movements outside the investigation area would be detected either by the ALS deployed near the Sinos River mouth or by the aerial surveys (which included considerable parts of the tributaries), these losses probably occurred due to fishing. If the loss of tagged fish is attributed to fishing, then more than $50 \%$ of the tagged fish were captured. This number corresponds to the findings of Godinho and Kynard (2006) who suspect that 17 of 37 tagged individuals were removed by fishing.

These figures highlight the impact of the heavy fishing pressure on the grumatã. Fishing evidently acts on the population level by decreasing the abundance of the individuals, and, additionally, on the genetic level. Machado et al. (2005) found that the genetic diversity of the dourado (Salminus brasiliensis Valenciennes, 1840), in the Sinos River, is eight times lower than in the greater and less intensively exploited Uruguay river. They attribute their findings either to a recent genetic bottleneck or to a small long-term effective population size, which could be a consequence of intensive fishery.

It may be suggested that the observed low swimming activity of P. lineatus in the Sinos River and the lack of a defined spawning migration are related to the fisherydependent selection of less mobile individuals. Migratory and resident grumatã populations were described downstream of Buenos Aires (Cabrera and Candia, 1964). Resident individuals were smaller (max. total length $40 \mathrm{~cm}$ ) than migrants $(\max .70 \mathrm{~cm}$ ). This observation corroborates with our result that heavier individuals are more mobile.

During our 20-month study, only one fish left the Sinos River. This result indicates that the Sinos River has a resident grumatã population. Adult fish do only stray into other rivers to a very small degree. This behaviour may contribute to genetic differentiation between stocks, as reported for salmonids (Bernatchez et al., 1992). In the case of decreased genetic diversity due to fishing, low genetic exchange between populations in different basins may enhance isolation processes and may lead to a genetic bottleneck in the grumatã population. 
The diel activity of adult grumatã in the Sinos river was similar to that of the congeneric P. nigricans, in a Peruvian reservoir. As in the Sinos, the tracked individuals were more active during the day with peaks of swimming activity in the morning and in the late afternoon (Mochek et al., 1991). Usually rhythmic diel activity occurs because of regular movements between habitat patches, frequently refuge and feeding habitats. These displacements are a trade-off between safe, but less productive and food rich but more dangerous habitats (Hall et al., 1979; Winemiller and Jepsen, 1998). Other purposes for diel activity are displacements because of homeostatic reasons, when changing environmental parameters like oxygen or temperature fall below or rise above tolerable physiological limits (Lucas and Baras, 2001). On the basis of the ALS registrations, it was not possible to identify the underlying reason for these movements, but it is clear that these displacements are longitudinal. Radio-tracked dace (Leuciscus leuciscus Linnaeus, 1758) in the River Frome moved longitudinally between refuge sites occupied during the day and foraging sites during night (Clough and Ladle, 1997). The distances travelled depended on habitat structures like length of riffle-pool sequences. In the Sinos River, further investigation of daily displacements of grumatã should be performed by mobile 24 hours tracking cycles to identify the habitat patches occupied during the day and during the night.

During rising water levels, tracking of grumatã became increasingly difficult. As the floodplain became inundated, fish moved from the River bed into the adjacent wetlands and stayed frequently in dense and inaccessible vegetation. On these occasions, the presence of a radio signal was detected, but due to the distance and dense vegetation it was not possible to decode and identify the individual.

Many studies confirmed the importance of wetlands as nursery areas (Agostinho and Zalewski, 1995; Agostinho et al., 1997). The present study showed the importance of wetlands for adult fish. During flooding with high flow velocities in the main channel, fish find extended refuge areas with almost stagnant water with access to allochtonous food resources. The observations during mobile tracking of the present study suggest that grumatã use wetland areas in the middle reach of the River Sinos as well for reproduction without performing characteristic long-distance spawning migrations

Climate conditions during the study were extremely variable. In 2002, the hydrologic regime was under the strong influence of the ENSO (El Niño Southern Oscillation) system which started with torrential rainfalls in September. The consequence was an extended flood period with permanently high water level during approximately 50 days from October to November 2002, reducing the characteristic short flood pulses during theses months to one single pulse of long duration. During this period, the tagged fish did not display higher distance covered, which could be expected due to the reproduction period. Activity increased in March 2003, after the spawning season, when water levels were raising again, but temperature decreased.
It was not possible to reveal if this increase in activity was related to delayed spawning or post spawning activities.

During the 2003/2004 spawning season, the situation followed another atypical pattern. From September to December, rainfalls occurred in intervals of several days, causing frequent flood pulses. The activity levels of the tagged fish increased from October 2003 on, and remained elevated until January 2004, when the water level was already decreasing. Due to these strong variations in the responses to environmental variables, eventually pooling more migratory with less migratory individuals might interfere strongly with the applied mathematical model, thus hindering statistically significant relationships.

According to the present results, we suggest that future conservation efforts of the grumatã population should focus on: a) the preservation of the still-existing wetlands, which exert an ecological key function as nursery, refuge and forage habitat for grumatã, and b) the control of fishery activity, which at present, may cause more serious impact than industrial and domestic sewage.

Acknowledgements - This work was supported by grants and fellowships from the Coordenação de Aperfeiçoamento de Pessoal de Nivel Superior (CAPES - Ministry Of Education) and from UNISINOS-University. Furthermore, the project received funding from the Ministry of the Environment. Dr. Emerson Vieira contributed to the manuscript with fruitful comments. We wish to thank all contributors.

\section{References}

ADAMS, SN., RONDORF, WD., EVANS, DS., KELLY, EJ. and PERRY, WR., 1998. Effects of surgically and gastrically implanted radio transmitters on swimming performance and predator avoidance of juvenil Chinook salmon. Canadian Journal of Fisheries and Aquatic Sciences, vol. 55, p. 781-787.

AGOSTINHO, AA. and ZALEWSKI, M., 1995. The dependence of the fish community structure and dynamics on floodplain and riparian ecotone zone in Paraná River, Brazil. Hydrobiology, vol. 303, p. 141-148.

AGOSTINHO, AA., GOMES, LC., SUZUKI, HI. and JÚLIO-JR, HF., 2003. Migratory fishes of the upper Paraná River Basin, Brazil. In CAROLSFELD, J., HARVEY, B., ROSS, C. and BAER, A. (Eds.). Migratory fishes of South America. Ottawa, Canada: The World Bank, p. 19-98.

AGOSTINHO, AA., JULIO-JR, HF., GOMES, LC., BINI, ML. and AGOSTINHO, SC., 1997. Composição, abundância e distribuição espaço - temporal da ictiofauna. In VAZZOLER, AEA., AGOSTINHO, AA. and HAHN, NS. (Eds.). A planície de Inundação do alto rio Paraná: aspectos físicos, biológicos e sócio - econômicos. Maringá: Universidade Estadual de Maringá, p. $179-208$

AGOSTINHO, AA., VAZZOLER, AEAM., GOMES, LC. and OKADA, EK., 1993. Estratificacion espacial y comportamiento de Prochilodus scrofa en distintas fases del ciclo de vida, en la planicie de inundación del alto rio Paraná y embalse de Itaipu, Paraná, Brasil. Revue d'Hydrobiologie Tropicale, vol. 26, p.79-90.

BAYLEY, PB., 1973. Studies on the Migratory characin, Prochilodus platensis Holmberg, 1889, (Pisces, Characoidei) in the River 
Pilcomayo, South America. Journal of Fish Biology, vol. 5, p. 25-40.

BERNATCHEZ, L., GUYOMARD, R. and BONHOMME, F., 1992. DNA sequence variation of the mitochondrial control region among geographically and morphologically remote European brown trout Salmo trutta populations. Molecular Ecology, vol. 1, p. 161-173.

BOWEN, SH., BONETTO, AA. and AHLGREN, MO., 1984. Microorganisms and detritus in the diet of a typical neotropical Riverine detrivore, Prochilodus platensis (Pisces, Prochilodontidae). Limnology and Oceonography, vol. 29, p. 1120-1122.

CABRERA, SE. and CANDIA, C., 1964. Contribución al conocimiento da la biologia del sábalo (Prochilodus platensis) del Rio de la Plata. Revista de Investigaciones Agropecuárias, vol. 1, p. 57-83.

CAROLSFELD, J., HARVEY, B., ROSS, C. and BAER, A. (Eds.), 2003. Migratory fishes of South America. Ottawa, Canada: The World Bank, 372 p.

CASTRO, RMC. and VARI, RP., 2003. Prochilodontidae (Fannel mouth characiforms). In REIS, RE., KULLANDER, SO. and FERRARIS-JR, CJ. (Eds.). Checklist of the Freshwater Fishes of South and Central America. Porto Alegre: EDIPUCRS, p. 65-70.

CLOUGH, S. and LADLE, M., 1997. Diel migration and site fidelity in a stream-dwelling cyprinid, Leuciscus leuciscus. Journal of Fish Biology, vol. 50, p. 1117-1119.

Conselho Nacional do Meio Ambiente - CONAMA, 1992. Resoluções do CONAMA. Brasília, DF: IBAMA.

ESPINACH-ROS, A. and DELFINO, R., 1993. Situación de las pesquerias de la Cuenca de la Plata en Paraguay, Bolívia, Argentina e Uruguay. FAO Informaciones de Pesca, vol. 490, p. 36-51.

FROESE, R. and PAULY, D., 2010. FishBase. Available from: <www.fishbase.org>. Access in: Feb. 2010.

FUGI, R.; HAHN, N.S. and AGOSTINHO, A.A. 1996. Feeding of five species of bottom feeding fish of the Paraná River (PR, MS, Brasil). Environmental Biology of Fishes, vol. 46, no. 3, p. $297-307$.

Fundação Estadual de Proteção Ambiental Henrique Luis Roessler - FEPAM, 1999. Qualidade das Águas do rio dos Sinos. Porto Alegre, RS: FEPAM.

GODINHO, AL. and KYNARD, B., 2006. Migration and Spawning of Radio-tagged Zulega Prochilodus argenteus in a Dammed Brazilian River. Transactions of the American Fisheries Society, vol. 135, p. 811-824.

GODOY, MP., 1959. Age, growth, sexual maturity, behavior, migration, tagging and transplantation of the Curimatá (Prochilodus scrofa Steindachner, 1881) of the Mogi Guassú River, São Paulo State, Brazil. Anais Academia Brasileira de Ciência, vol. 31, p. 447-477.

-, 1962. Migração e Transplantação de Peixes Marcados na Bacia do Rio Paraná Superior. Arquivos do Museu Nacional, vol. 52, p. $105-113$.

GOMES, LC. and AGOSTINHO, AA., 1997. Influence of the flooding regime on the nutricional state and juvenile recruitment of the curimba, Prochilodus scrofa, Steindachner, in Upper Paraná, Brazil. Fisheries Management and Ecology, vol. 4, p. 263-274.
HALL, DJ., WERNER, EE., GILLIAM, JF., MITTELBACH, GG., HOWARD, D. and DONER, CG., 1979. Diel foraging behavior and prey selection in the golden shiner (Notemigonus chrysolucas). Journal of the Fisheries Research Board of Canada, vol. 36, p. 1029-1039.

LUCAS, MC. and BARAS, E., 2001. Migration of freshwater fishes. London: Blackwell Science, $420 \mathrm{p}$.

MACHADO, V., SCHULZ, U., PALMA, LP. and RODRIGUES, JJS., 2005. Mitochondrial DNA variation and genetic population structure of the migratory freshwater fish dourado Salminus brasiliensis (Characidae). Acta Biologica Leopoldensia, vol. 27, p. 107-113.

MOCHEK, AD. and PAVLOV, DS., 1998. The ecology of sabalo Prochilodus lineatus (Curimatidae, Characoidei) of the Pilcomayo River (South America). Journal of Ichthyology, vol. 38 , p. 28-36.

MOCHEK, AD., P'YANOV, AI. and SARANCHOV, SI., 1991. Results of telemetric tracking of Prochilodus nigricans in a forest reservoir (Peru, Ucayali Department). Journal of Ichthyology, vol. 31 , p. 115-119.

ROSGEN, DL., 1994. A classification of natural Rivers. Catena, vol. 22, p.169-199.

SCHUBART, O., 1954. A piracema Rio Mogi-Guassú (Estado de São Paulo). Duzenia, vol. 5, p. 49-59.

SCHULZ, UH. and BERG, R., 1987. The migration of ultrasonictagged bream, Abramis brama (L), in Lake Constance (Bodensee - Untersee). Journal of Fish Biology, vol. 31, p. 409-414.

SCHULZ, UH. and LEUCHTENBERGER, C., 2006. Activity patterns of the South American silver catfish (Rhamdia quelen). Brazilian Journal of Biology, vol. 66, p. 565-574.

SCHULZ, UH., 2003. Effects of surgically implanted dummy transmitters on the South American Catfish Jundiá (Rhamdia quelen). Brazilian Journal of Biology, vol. 63, p. 345-348.

SVERLIJ, SB., ESPINACH-ROS, A. and ORTI, YG., 1993. Sinopsis de los datos biológicos y pesqueros del sábalo Prochilodus lineatus (Valenciennes, 1847). FAO Synopsis sobre la Pesca, vol. 154 , no. 64 .

SVERLIJ, SB., ESPINACH-ROS, A. and GERACITANO, A., 1992. Estrutura de idades de os efectivos de sábalo Prochilodus lineatus (Pisces, Prochilodontidae) del rio Uruguay inferior. Publicaciones de la Comissión Administradora del Rio Uruguay (CARU), Serie Técno-Científica, vol. 1, p. 54-62.

TRAVINCHEK, VH., 2004. Movements of flathead catfish in Missouri River: Examining opportunities for managing River segments for different fishery goals. Fisheries and Ecological Management, vol. 11, no, 2, p. 89-96.

WINEMILLER, KO. and JEPSEN, DB., 1998. Effects on seasonality and fish movement on tropical food webs. Journal of Fish Biology, vol. 53, suppl. A, p. 267-296.

YOUNG, MK., 1999. Summer diel activity and movement of adult brown trout in high-elevation streams in Wyoming. Journal of Fish Biology, vol. 54, p. 181-189.

ZANIBONI, EF. and SCHULZ, UH., 2003. Migratory fishes of the Uruguay River. In CAROLSFELD, J., HARVEY, B., ROSS, C. and BAER, A. (Eds.). Migratory fishes of South America. Ottawa, Canada: The World Bank, p. 157-194. 